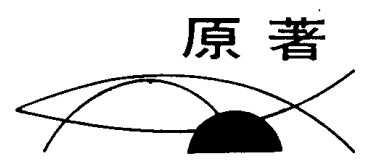

\title{
紫外線殺菌装置の各種細菌およびウイルス に対する殺菌効果に関する研究
}

\author{
川名林治* 前川裕子*
}

\author{
Studies on the Microbialcidal Effects on Ultra-Violet Sterilizer \\ against Several Kinds of Bacteria and Viruses
}

Rinji KAWANA, Yuko MAEKAWA

Department of Bacteriology, School of

Medicine Iroate University, Morioka, Japan

\begin{abstract}
This study was performed for the purpose of determining the effects of ultraviolet ray against several kinds of bacteria and viruses. The experimental method was to eradiate ultraviolet ray with some distance, against petri dishes containing some bacteria or viruses.

Following results were obtained:

(1) With one minute eradiation of ultraviolet ray, E. coli, Pseudomonas aeruginosa, Serratia marcescens, Klebsiella pneumonia and Staphylococcus aureus were decreased in number by $1 / 1,000$. They were almost killed with five to ten minutes eradiation.

(2) Herpes simplex virus type I, Parainfluenzavirus type 3 and Rhinovirus type 13 were completely inactivated after being eradiated to ultraviolet ray for five minutes.

(3) Coxsackie B3 and Adenovirus type 3 were inactivated by about one half after fiveminutes eradiation to ultraviolet ray.

Judging from the results of these experiments, it can be said that this ultraviolet ray eradiation apparatus has an excellent microbialcidal activities not only against bacteria but also to viruses. This apparatus may be useful for the control of the nosocomial infection.
\end{abstract}

* 和手医科大学医学部細菌学教空

(稿受付：㸛和57年:10月13日) 


\section{ま え がき}

紫外線殺菌灯による殺菌法は, 近年院内感 染防止の面からも広く応用されるに至ってい る. ${ }^{1 \sim 4}$ 種々のものが工夫されているが，最近製 造市販された紫外線殺菌装置（スペースライザ 一,豊田メディカル制造， TMS-304M）は，紫外線ランプ GL-30 を 4 本 と, 底部に GL-81 本を装置するなど独創的に 考案されたものとして注目されている1”。

私たちは本装㯰の殺菌効果を検討するため, 種々の細菌およびウイルスを対象として実験を すすめた結果, 強力な効力を有するごとを認め たので，その成䋡の概要について報告したい．

\section{実 験 方 法}

\section{1. 使用装置}

移動式室内殺菌装圆 (TMS-304M) を用い， 一定時間殺菌灯を照射した，実験はすべて当教 室のバイオクリーン・ルーム内で実施した。

衰 1 仕椂

\begin{tabular}{|c|c|}
\hline 式 & TMS $-304 \mathrm{M}$ \\
\hline \multirow[t]{2}{*}{ 電圧周 波 数 } & $\mathrm{ACl} 100 \mathrm{~V}, 50 / 60 \mathrm{~Hz}$ \\
\hline & $\begin{array}{l}\text { (3芯コート，プラグ, } 5 \mathrm{~m} コ ー \\
\text { 卜付) }\end{array}$ \\
\hline 消 費 電 力 & $170 \mathrm{~W}$ \\
\hline \multirow[t]{2}{*}{ 柴外線 ランプ } & GL $-30 \times 4$ 本 \\
\hline & GL $-8 \times 1$ 本 \\
\hline ランプ有効寿命 & 3000時間 \\
\hline 製 品 重 量 & $28 \mathrm{~kg}$ \\
\hline 寸 & $\begin{array}{l}\text { 幅 } 940 \times \text { 奥行 } 940 \times \text { 高1, 250(men) } \\
\text { 取大寸法 }\end{array}$ \\
\hline
\end{tabular}

\section{2. 使用微生物}

1）使用細菌

教室に保存してある次の菌を使用した．

（1）大腸菌

(2) 黄色ブドウ球菌

(3) クレブシェラ・ニューモニエ

(4) 緑膿菌

(5) セラチア・マルセッセンス

2) 使用ウイルス

(1)、単純ヘルペスウイルス 1 型

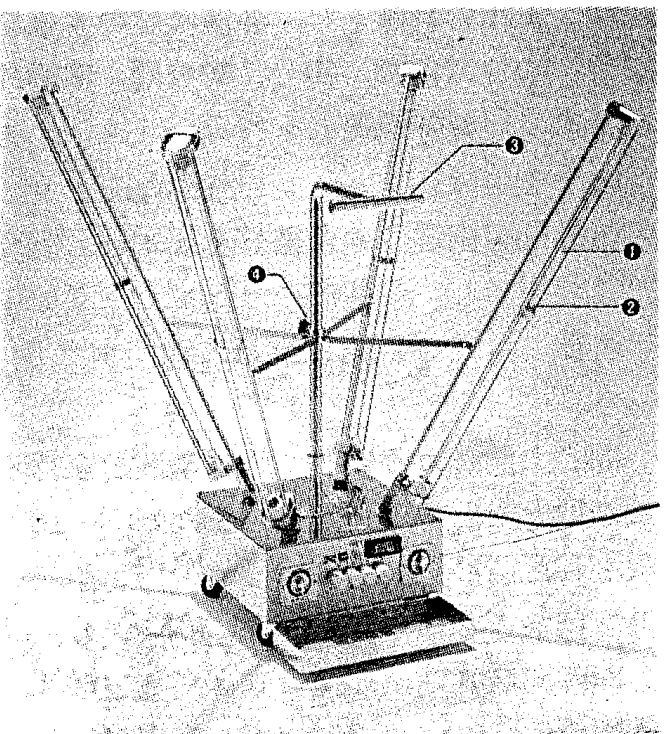

图 1 移勤式害内殺菌装是（スペースライザ） 使用時

(1)殺菌ランプ (2)ランプガード (3)ハン ドル (4)固定金具

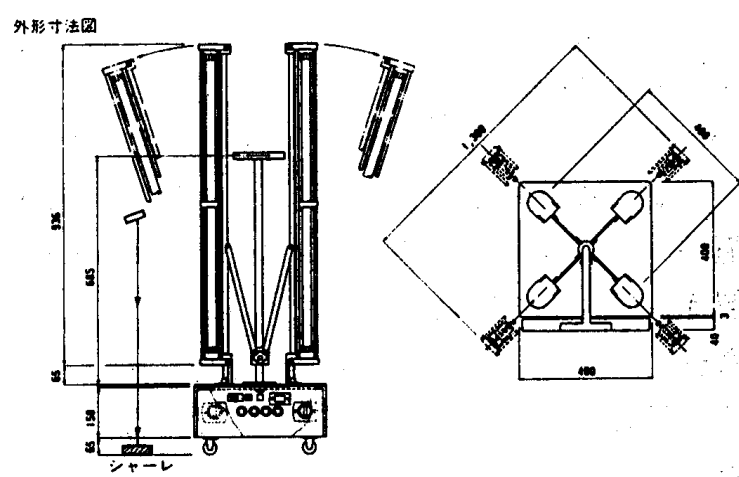

图 2 スペースライザ

(2) アデノウイルス 3 型

(3) パラインフルエンザウイルス３型

(4) ライノウイルス 13型

(5) コクサッキーウイルスＢ３型

\section{3. 実験操作}

1）細菌の場合

（1）上述の細菌はそれぞれ別個に実験をす すめた。 普通寒天培地に $37^{\circ} \mathrm{C} 24$ 時間培趇した ものを验菌し、これらのそれぞれ $10^{9} / \mathrm{ml}$ の細 菌浮遊液を生理食塩水で調製する。

（2）それらを菌原液として，10-8まで希釈 し, $10^{8} / 0.1 \mathrm{~m} l \sim 10^{5} / 0.1 \mathrm{~m} l$ の菌湌度のものを それぞれ $0.1 \mathrm{~m} l$ ずつ普通寒天培地を入れた直 径 $9 \mathrm{~cm}$ のペトリー・シャーレ内の平板に, コ ンラージ棒で十分にひろげ坥抹する. 
（3） 1 枚を対照とし, 各菌濃度の平板培地 を 1 分, 5 分, 10 分, 20 分, 30 分間, 本紫外線 殺菌装置で，紫外線照射を行ら。

（4）その際：シャーレの外ぶたをとり，ま た本紫外線殺菌装置の殺菌灯を 4 本とも完全に 広げた状態にし，殺菌灯のランプガードの中央 直下に置く．その距離は平板培地面まで $64 \mathrm{~cm}$ である。

（5）上記のようにして紫外線照射を行った 平板培地と対照の平板培地, また $10^{-5} \sim 10^{-8}$ に 希釈された菌液を同様に $0.1 \mathrm{~m} l$ ずつ塗沫した ものを菌液の 2 次定量として, $37^{\circ} \mathrm{C}$ の子卯器 で，24時間培養し，そのコロニ一数を計算した。 紫外線殺菌灯は G L $-30 \times 4$ 本, 底面に G L $-8 \times$ 1 本となっている。

2) ウイルスの場合

(1)上述の各ウイルスの組織培養して得ら れた原液を, 各ガラス製ぺトリーシャーレに $1 \mathrm{~m} l$ ずつ分注し，均等になるように広げる。 シ ヤーレは $9 \mathrm{~cm}$ の底面の完全に平らなものを用 いた。

（2）細菌の場合と同様に，本柴外線殺菌装 置のランプガードの中央直下に外ぶたをとって 置き，それぞれ同量の同力他のウイルスの入っ たペトリーシャーレを, 1 分, 5 分, 10 分, さ らに必要に忘じて20分，30分間と紫外線照射を 行った.

(3) 紫外線照射が終わったなら，直ちに $9 \mathrm{~m} l$ の Eagle’s MEN を加え, よく混和したのち, 滅菌スピッッ管に回収する。

(4) 水中にて, ウイルス液を10倍階段希釈 し，用意しておいた組織培養細胞に接種し，ウ イルス力他の測定を行う，定量法はマイクロタ イター法を用いた。

（5）細胞はあらかじめマイクロプレートに， HeLa 細胞または Vero 細胞を $3 \times 10^{4} / \mathrm{m} l$ ま いておき，3日目に $2 \%$ ウシ血清加 Eagle’s $\mathrm{MEM}$ で液交換をしたものを用いた。

(6) $0.025 \mathrm{ml}$ ずつ，ドロッパーでウイルス を組織培養細胞に接種後, $37^{\circ} \mathrm{C}$ で $5 \% \mathrm{CO}_{2}$ 培養 子卵器で培養を行い, 毎日細胞変性効果 (CPE) の観察を行った。

(7) ウイルス詨照としては，ウイルス原液
そのものを紫外線照射時間を 0 とし, $1 \mathrm{~m} l の ウ$ イルス液を $9 \mathrm{~cm}$ のペトリーガラスシャーレに 広げて, 10分間, 場合によっては30分間室温に 放置したものを用いた。

\section{実 験 成 績}

実験の結果はおおむね次のとおりである。

\section{1）細菌の場合}

(1) 大腸菌

$2 \times 10^{6}$ の場合は 5 分間位で, $2 \times 10^{8}$ では 10 20 分くらいでほとんど死減する．極めて紫外線 が有効であった．両者の場合とも 1 分間ですで

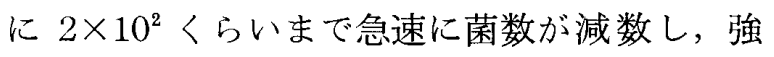
い殺菌効果のあることが認められた。

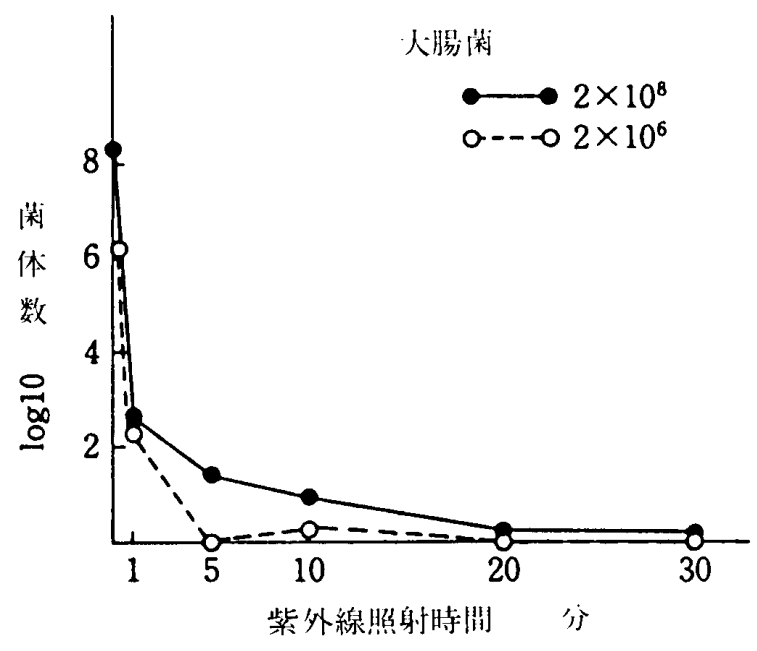

図 3

(2) 黄色ブドウ球菌

この場合も, $2 \times 10^{8}, 2 \times 10^{6}$ いずれも 1 分間 で急速に $10^{2}$ 台まで減数し，ことに後者では 5 分間で 0 となる．前者では20〜30分間を要し, 菌数によって差がみら扎た。

(3) クレブシエラ・ニューモニエ

$2 \times 10^{8}, 2 \times 10^{6}$ の雨者ともやはり, 1 分間で $10^{2}$ 台まで急速に減数する，前者では約 20 分, 後者では 5 分間で 0 となり，この場合にも強力 な殺菌効果のあることが認められた.

(4) 緑膿菌

$2 \times 10^{6}$ では，1 分間でほとんど 0 に近く， 5 分間で完全に殺菌されるが， $2 \times 10^{8}$ では，約20 〜30分を要し，菌数による差がみられた。

(5) セラチア・マルセッセンス

$1 \times 10^{6}$ では, $10^{1}$ 台に 1 分間で， 5 分間で 0 


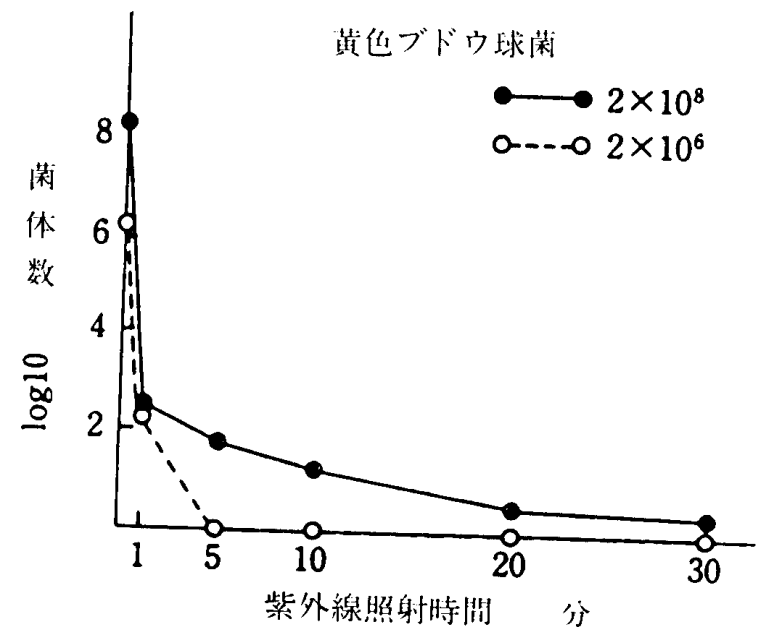

図 4

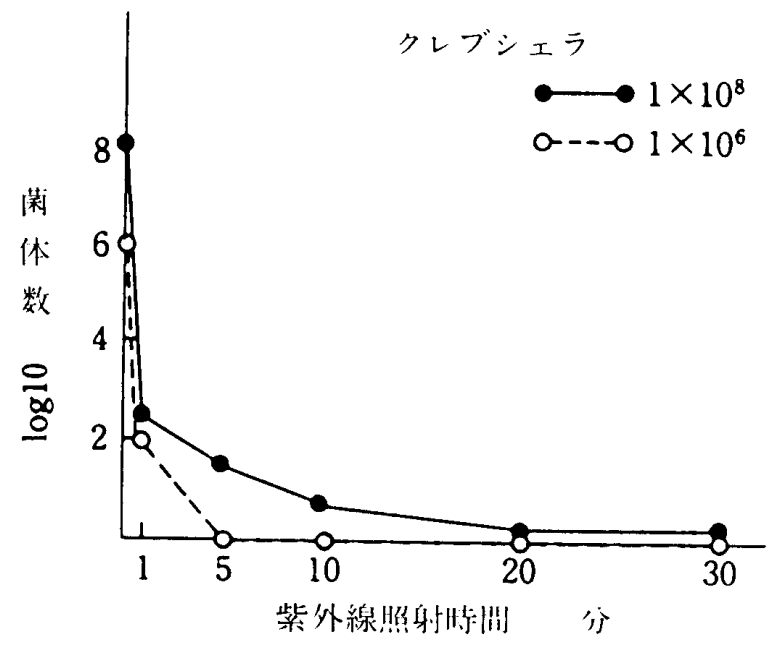

图 5

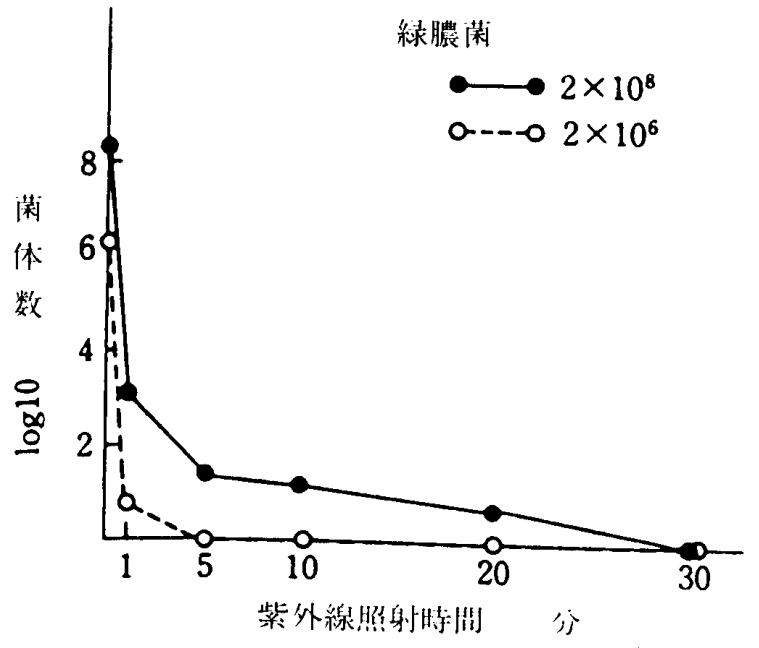

図 6

となる. $1 \times 10^{8}$ では, 1 分間で $10^{2}$ に, その後 は20分から30分で 0 と漸次減数する。

\section{2）ウイルスの場合}

各紫外線照射時間とウイルス力侢との関係は 次のようであった。

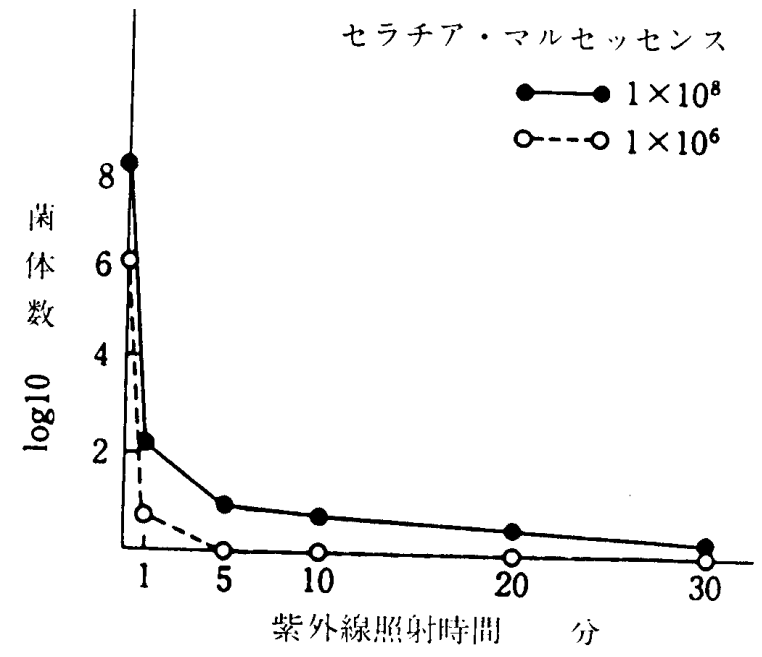

図 7

(1) 単純ヘルペスウイルス 1 型

ウイルス力価を TCID $50 / 0.025 \mathrm{ml}$ で示すと， $10^{5}$ から 1 分でやや減り, 5 分閒では 0 となり, 本ウイルスに対し, 強力なウイルス不活化作用 のあることがみられた。

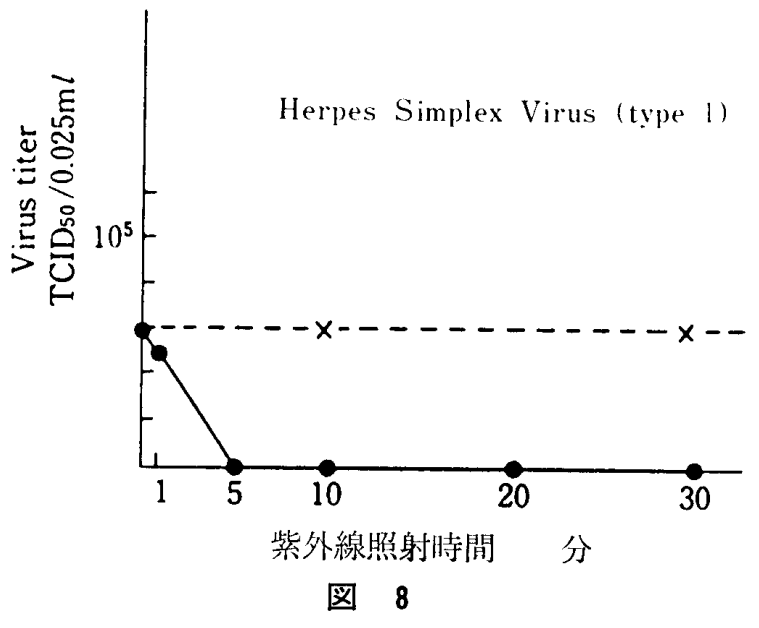

(2) アデノウイルス 3 型

比較的抵抗性を示し，10分から30分間で約 $1 / 2$ に力洒が低下した．これはおそらく遊離ウイル スは速やかに不活化されるが，細胞内のウイル スには直接紫外線の作用が及ぶのに困難である と推定された。

(3) パラインフルエンザウイルス 3 型

この場合も，1分間でやや減り，5分間では 完全に不活化される. 紫外線の強いウイルス不 活化作用を認めた。

\section{(4) ライノウイルス13型}

紫外線照射後 1 分, 5 分, 10 分間と徐々にウ イルス力㑋が減り，20分間で 0 となる。イノ 


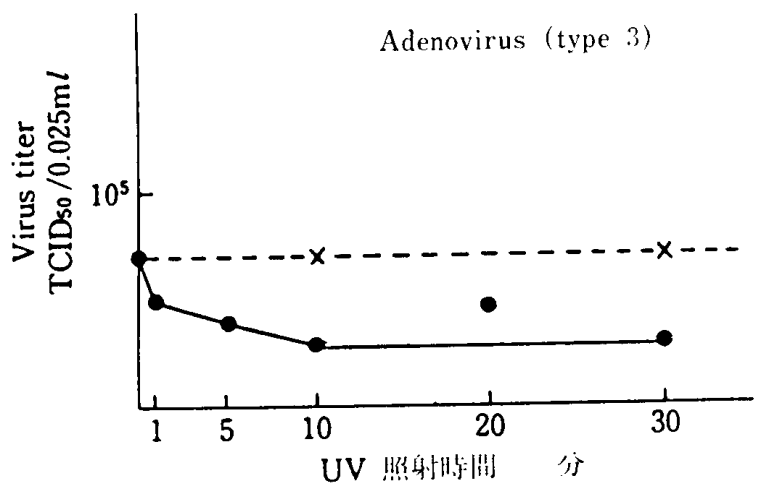

図 9
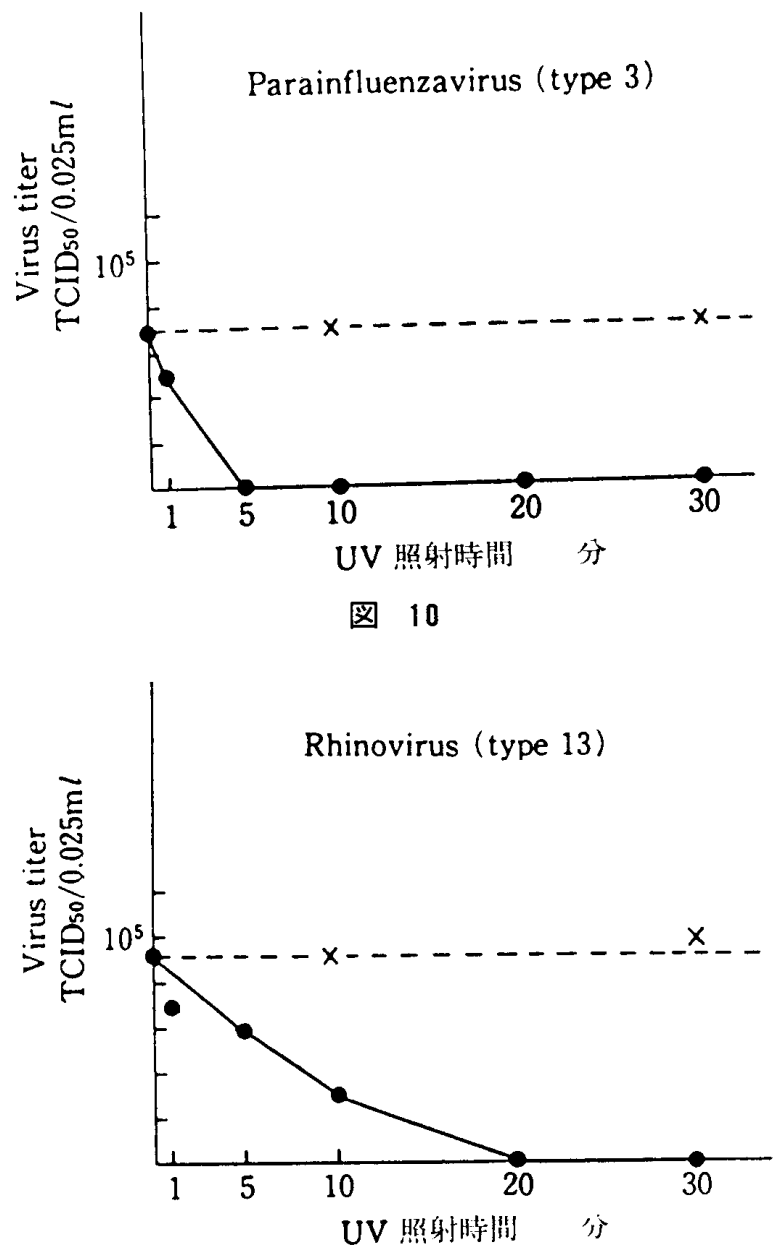

図 11

ウイルスに対しても，紫外線の効果を確認でき た。

(5) コクサッキーウイルス 3 型

かなり高いウイルス力価, 寸なわち TCID $50 / 0.025 \mathrm{~m} l$ で, $10^{7}$ ものが，漸減したが， 10 分, 20 分, 30 分間と, ほぼ平行的であった。 の場合もアデノウイルスのように細胞外のウイ ルスには直ちに紫外線が有効に作用するが, 細 胞内のウイルスには十分な作用が及泣ないので

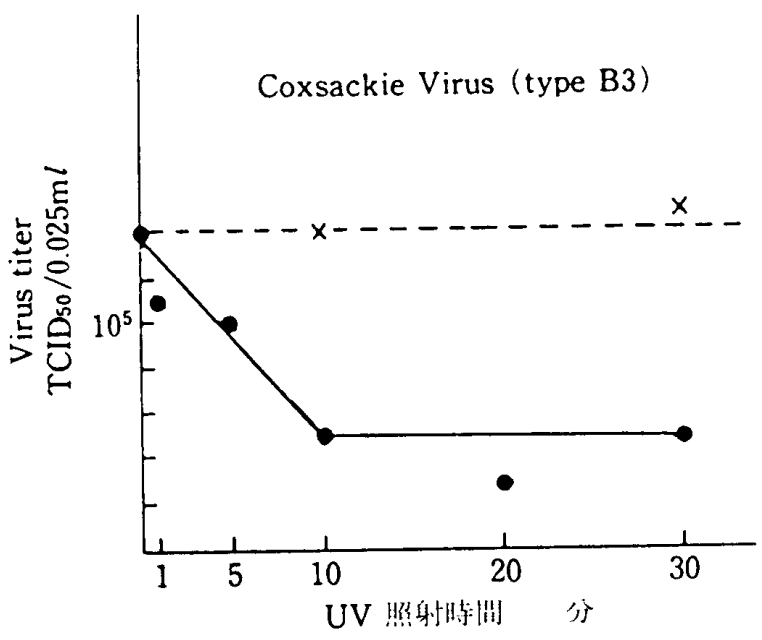

図 12

はないかと思われた。

\section{考察}

細菌およびウイルスに対する本紫外線殺菌装 置の効果を判定する目的で実験をすすめた.

従来加紫外線の細菌に対する殺菌効果に関

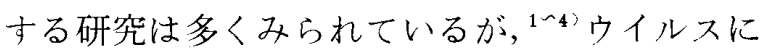
ついての研究は極めて少なく，本実験で用いた ように, 本紫外線殺菌装置による種々のウイル スに対する不活化作用に関寸る研究はみられな かった。

本紫外線殺菌装置の殺菌効果は細菌の場合 $10^{8}$ のオーダーの菌数のものと $10^{6}$ のオーダーの ものを比較すると，1060場合には極めて有効 であるといえる．上゙の細菌についても 1 分間で 寸でに著しい減数が認められ，5分間の照射で はす心゙てのものが死滅している．10 $0^{8}$ の場合に は, やはり 5 分間くらいでかなり減数するが, 30分間の照射でも $1 \sim 3$ בくらい残る場合も女 り，また 1 分から10分間くらいの照射では, シ ヤーレの周辺部付近に残るものが多く, 紫外線 の直射のかげになる部分が多少あることが推定 された。

またウイルスについては，それぞれのウイル スによって, 本紫外線殺菌装置の不活化効果が 異なっている．単純へルペスウイルス１型やパ ラインフルエンザウイルス 3 型の場合では， 5 分間の照射でウイルスが完全に不活化されてい る.このことからエンベロープを有するこれら のウイルスに対しては強力な作用を与えるもの 
医器学 Vol. 53, No. 6 (1983) (21)

と思狆る。また細胞外のウイルスの多いこと も推定される。

原液のウイルスの力㑣にもよる上思われるが， 遊離ウイルスと細胞内ウイルスが混在している とも考えられるアデノウイルス 3 型およびュク サッキーウイルス 3 型などは, 比較的他の物理 化学的影響にも抵抗性をみるが，本奏験におい ても不活化寸るのに長恃間を要した。

ライノウイルス13型の場合は，30分間くらい の間に次第に不活化され, 本紫外線殺菌装置が 有用であることを認めた。

いずれにせよ, 本紫外線殺菌装置は, 本実験 の成績からみて, 細菌およびウイルスに対して, 強力な殺菌ないしは不活化効果のあるこ上を確 認した。

本実験に使用した細菌およびウイルスはいず れも多数菌あるいは高力侢のものでありながら， 本紫外線殺菌装置は優れた作用を示していた。

滅菌, 消毒などには種々の方法があり，また 紫外線殺菌灯にもいろいろのものがあるが，本 紫外線殺菌装置は可動式で，しかも四灯式であ り，しかも底面につけた殺菌灯なじ工大がされ ている.

本器による空中細菌の殺菌効果はことに照射 後数分間で, 浮遊菌数が激減し有意の差を認め, また付着細菌においても效果があるというが1， 私たちの今回の実験では，ウイルスおよび細菌 について極めて有効であることを確認したもの といえる。

院内感染防止の面ですでにわれわれは殺菌灯 を広く活用しているが ${ }^{5,6}$ 本紫外線殺菌装置が その特徵的な細菌の殺菌, ウイルス不活化作用 を発揮し, 広く臨床各科はもとより手術室 ICU, $\mathrm{CCU}, \mathrm{NICU}$, さらに中央材料部, さらに研究 室の照射面の無菌化拉よび室内空気の清浄化な どのため，とくに院内感染防止に応用されるこ とを期待したい.

本紫外線殺菌装置の殺菌効果を検討する目的 で，数種の細菌およびウイルスを対象として来 験を行った。

実験方法は一定数の細菌あるいはウイルスを 入れたガラスペトリーシャーレの上ぶたをとり， これに一定の距離で紫外線を照射した。
その結果, 黄色ブドウ球菌, 大腸菌, クレブ シェラ・ニューモニエ, 七ラチア・マル七ッ七 ンス, 緑膿菌などには紫外線照射は極めて有効 であり，照射 5 分間位で菌数は激減し，少なく とも1/1000位になり長くとも30分以内に完全に 死滅させることができた。

一方，単純へルペスウイルス 1 型，パライン フルエンザウイルス 3 型では 5 分間で，ライ， ウイルス 13 型は20分間で全く不活化することが できた。コクサッキーウイルス B 3 型やアデ， ウイルス 3 型にはやや長時間を要した。

以上の結果から，種々の点で改良工夫された 紫外線殺菌装置である本器は細菌のみならず, ウイルスに対しても強力な殺菌ないしウイルス 不活化効果を示寸ことを確認した。とくにウイ ルスに対子る作用については新たな知見である といえる.

本紫外線殺菌装置の創意された構造と機能は, 院内感染防止のためにも今後大いに活用される ベき有用な装置であると考える。

ご教示くださんた豊閔メディカル㫼およびエ ムエス株に深謝する。

\section{文献}

1) 酒井順哉, 藤村 風, 大川 満：川動式室内紫外 線殺菌装置の無指向性配光曲線とその效果, 医科 器械学 $52(6), 286-292,1982$.

2) 日本医科器械学会監修, 綿貫 啙, 尖川偣:太郎, 柛原欣作編：減菌法 - 消毒法，第 1，2，3，4集， 文光裳, $1974,1979,1976,1979$.

3) Block, S. S. ed: Disinfection, Sterilization, and Preservation. '2nd Edition., Lea \& Febiger, Philadelphia, 1977.

4) Benarde, M. A. ed : Disinfection. Marcel Dekker, Inc., New York, 1970.

5）川名林治編：岩手医科大学:医学部・歯学部附属病 院，院内感染予防のためのマニュアル，岩手医科 大学院内感染刘策委員会, 1982.

6）川名林治：ウイルスによる院内感染とその対策， ウイルス. 32(1)21-33, 1982. 